\title{
Body type of cows as a factor of their productive longevity
}

\author{
I.M. Donnik, O.S. Chechenikhina*, O.A. Bykova, O.G. Loretts, and A.V. Stepanov \\ Ural State Agrarian University, 620075 Yekaterinburg, Russian Federation
}

\begin{abstract}
The purpose of these studies was to assess the influence of Russian Black Pied cows' body types on their productive longevity. The studies were conducted on the basis of enterprises of the Sverdlovsk region specializing in breeding of Russian Black Pied cattle. Most heifers were of the complex class "Excellent" (36.0\%), less of "Satisfactory" (6.0\%). The second largest class was "Good with a plus" $(28.0 \%)$. A complex class of animals affects their milk production. When selecting first-calf heifers, taking into account the body type, it seems possible to obtain animals of a conformation complex class not lower than "Good"; to obtain at least 5000$5500 \mathrm{~kg}$ of good quality milk with a mass fraction of fat of $3.85-3.88 \%$ and protein fraction of $3.06-3.08 \%$ from cows of 305 days of lactation, depending on the potential of the breeding herd; to increase the duration of production use up to 4.3-6.8 lactations; to increase the level of lifelong yield to $29637.0-38126.8 \mathrm{~kg}$ of milk.
\end{abstract}

\section{Introduction}

In modern conditions of extensive use of industrial technologies, there is a need for breeding highly productive animals that are well adapted to intensive conditions of use [1-3]. When analyzing data on the evaluation of cows' conformation, many authors came to the conclusion that the body type, as a factor, significantly affects the milk yield and it is one of the main breeding traits in the improvement of Russian Black Pied cattle [4-9].

Cows of strong, dense proportional composition, having a height at the withers of at least $130 \mathrm{~cm}$, stretched, with widely set, strong limbs and well-developed dairy forms are distinguished by increased productive longevity [10-16].

All this indicates not only desirability, but also the urgent need to assess cows' body types in breeding enterprises, to study the relationship between the conformation and the milk yield, and duration of the productive use of animals.

The objective was to assess the influence of body type of Russian Black Pied cows on their productive longevity.

\footnotetext{
* Corresponding author: olgachech@yandex.ru
} 


\section{Materials and methods}

The studies were conducted on the basis of enterprises of the Sverdlovsk region specializing in breeding of Russian Black Pied cattle.

In the work we used the records of individual journals of cows, milk records, data from the "SELEKS" information management system for the period from 2015 to 2019. 650 cows of different ages were evaluated by their conformation, of which 185 were first-calf heifers.

When studying the influence of a linear assessment of the conformation on the milk yield, 4 groups of first-calf heifers were formed depending on the conformation complex class. The first group is an "Exceptional" complex class; the second group is "Excellent"; the third group is "Good with a plus"; the fourth is "Good"; the fifth is "Satisfactory".

Conformation assessment was carried out according to the method "Assessment of the conformation of dairy cattle" from day 30 to 120 of lactation by three main methods: free eye assessment (body type), assessment by measurement (taking measurements) and point (dashed) rating. The studies were carried out according to two assessment systems (system A - linear; system B - comprehensive) in accordance with the requirements of the "Rules for the assessment of daughters of stud bulls of dairy and meat breeds SNPlem R-96" and international standards. In this case, we used the method of measuring cows using tools: a measuring stick, a measuring tape, a pair of compasses and a cutimeter. Based on the measurement results, the physique indices were calculated.

A comprehensive assessment was carried out on a 100-point scale. In this case, the overall score was established by the formula:

$$
O S=T V^{*} 0.10+D T^{*} 0.15+L^{*} 0.15+U^{*} 0.40+G A^{*} 0.20,
$$

where OS is the overall score

$$
\begin{aligned}
& \text { TV - torso volume } \\
& \text { DT - dairy traits } \\
& \text { L - legs } \\
& \text { U - udder } \\
& \text { GA - general appearance }
\end{aligned}
$$

The milk yield was evaluated in accordance with the "Rules for assessing the milk yield of cows of milk and meat breeds SNPplem R23-97". Milk yield rate and quality indicators of milk were evaluated monthly according to the results of control milking. The mass fraction of fat and protein was determined individually from each animal by using the "Klever 1M" milk quality analyzer.

Based on the obtained material, a database was created in Microsoft Excel and a biometric processing was performed with the calculation of the main parameters.

\section{Results and discussion}

Body shape indexes of cows give not only a more complete description of the conformation, but also the ability to evaluate the general constitutional type of the animal (Table 1).

It was found that in terms of the body elongation of the first-calf heifer, they lag behind the standard dairy type by $6.4 \%$. This indicates that the studied animals had a less stretched body relative to their height (size). 
Table 1. Body shape indexes of first-calf heifers of Russian Black Pied breed, in $\% \overline{\mathrm{X}} \pm S_{\bar{X}}$

\begin{tabular}{|c|c|c|}
\hline Body shape index & Index value & $\begin{array}{c}\text { Dairy type standards } \\
\text { (Krasota V.F. et al., 1990) }\end{array}$ \\
\hline Elongation & $113.6 \pm 1.5$ & 120.0 \\
\hline Blockiness & $129.6 \pm 1.1$ & 118.0 \\
\hline Pectoral & $64.6 \pm 1.3$ & 61.8 \\
\hline Overgrowth & $103.3 \pm 0.2$ & 100.9 \\
\hline Ischium overhang & $170.6 \pm 1.9$ & 147.5 \\
\hline Boniness & $15.4 \pm 0.5$ & 14.6 \\
\hline Pelvic-pectoral & $85.9 \pm 0.8$ & 80.2 \\
\hline
\end{tabular}

In all other values of body indexes, the studied cows surpass the standard of dairy type animals. For example, the blockiness index is $11.6 \%$ higher than the standard; the ischium overhang index - by $23.1 \%$ and the pelvic-pectoral index - by $5.7 \%$.

The pectoral index, which characterizes the width of the chest behind the shoulder blades relative to its depth, turned out to be higher than the standard by only $2.8 \%$, the overgrowth index - by $2.4 \%$.

The boniness index is slightly higher than the standard value, the difference in this case was only $0.8 \%$.

As a result of a linear assessment of the conformation according to system A, it was found (Figure 1) that the first-calf heifers had average size, firmness, sacrum length, pelvic position, muscularity at sacrum and thighs, length of the front pair of mammary glands, height of the hind pair of mammary glands and nipples' length.

In addition, cows had an average setting position of hind legs and hoof angle. At the same time, the studied cows had shallow torso thickness, narrow pelvis, and a poorly expressed furrow of the udder.

\begin{tabular}{|c|c|c|c|c|c|}
\hline Indices & $\begin{array}{c}\text { Minimu } \\
\mathrm{m} \\
\text { deviation } \\
\mathrm{s} \\
\end{array}$ & - & $\begin{array}{c}-0.9 \ldots \ldots-0.7 \ldots-0.5 \ldots-0.3 \ldots \ldots- \\
0.1 \ldots .0 \ldots+0.1 \ldots+0.3 \ldots+0.5 \ldots+0.7 \ldots+0.9\end{array}$ & + & $\begin{array}{c}\text { Maximu } \\
\mathrm{m} \\
\text { deviatio } \\
\mathrm{ns}\end{array}$ \\
\hline Height & short & & & 0.3 & tall \\
\hline $\begin{array}{l}\text { Torso } \\
\text { thickness }\end{array}$ & shallow & 1.6 & & & deep \\
\hline Firmness & weak & & & 0.5 & strong \\
\hline Dairy traits & $\begin{array}{c}\text { poorly } \\
\text { expressed }\end{array}$ & & & 1.1 & $\begin{array}{c}\text { expresse } \\
\mathrm{d}\end{array}$ \\
\hline $\begin{array}{l}\text { Sacrum } \\
\text { length }\end{array}$ & short & & & 0.3 & long \\
\hline $\begin{array}{l}\text { Pelvis } \\
\text { position }\end{array}$ & elevated & & & 0.4 & omitted \\
\hline Pelvis width & narrow & 2.4 & & & wide \\
\hline Muscularity & weak & & & 0.3 & strong \\
\hline $\begin{array}{l}\text { Position } \\
\text { setting of } \\
\text { hind legs }\end{array}$ & straight & & & 0.3 & curved \\
\hline Hoof angle & sharp & & & & obtuse \\
\hline $\begin{array}{l}\text { Attachment } \\
\text { of front } \\
\text { mammary } \\
\text { glands }\end{array}$ & loose & & & 0.7 & tight \\
\hline
\end{tabular}




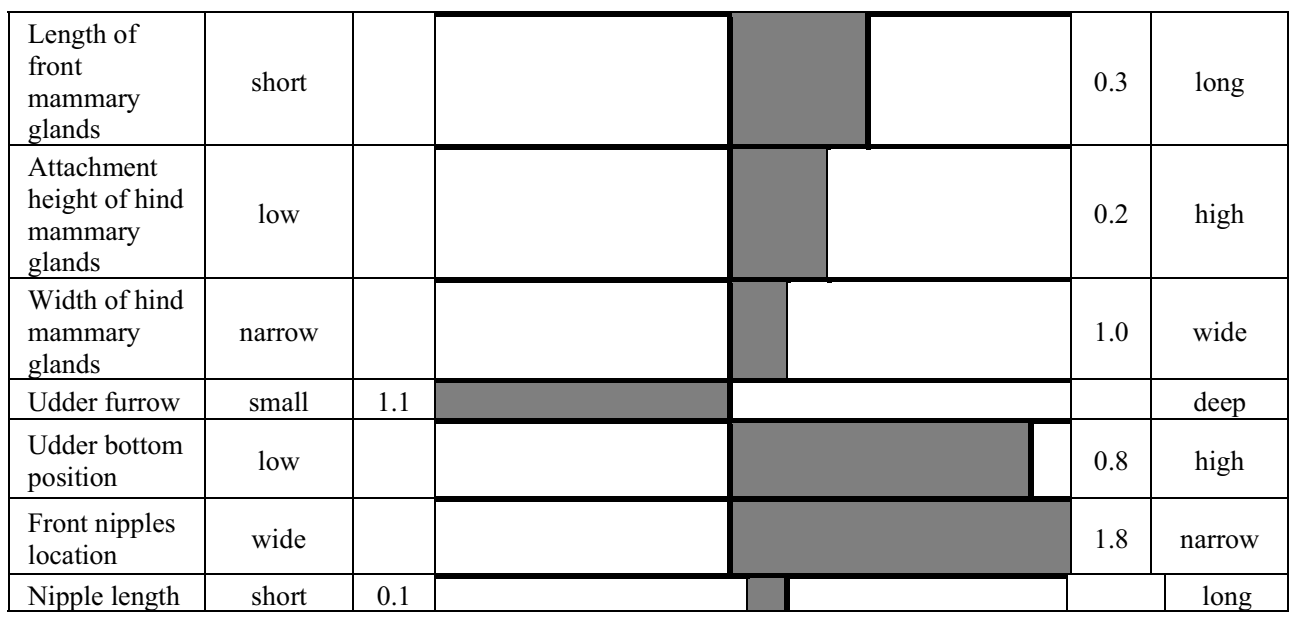

Fig. 1. Conformation profile of first-calf heifers of Russian Black Pied breed

(the center line on the graph, which is a zero mark, corresponds to index assessment at the average score ( 5 points). Deviations to the right or left of the center line indicate an increase in a particular biological extreme)

Cows of this herd had well-defined dairy forms with fairly wide hind mammary glands tightly attached to the body. The position of the udder bottom was high, with a wide space between the front nipples.

Indicators of a comprehensive assessment of the conformation (system B), which are determined in accordance with a linear assessment of the characteristics, are presented in Table 2.

The first-calf heifers received a greater number of points for the torso volume $(86.8$ points) and the dairy traits expressness ( 87.0 points). The animals scored fewer points for the udder ( 83.7 points) and legs development ( 84.7 points).

This assessment is carried out with the obligatory allowance for the defects and shortcomings of the studied animals. In our group of heifers, the main physique deficiencies were: proximity of the hock joints $-10.1 \%$; inclined udder bottom $-8.7 \%$; additional nipples $-7.3 \%$; closely spaced hind nipples $-6.2 \%$. More than half of the animals $(55.0 \%)$ showed no deficiencies of the conformation.

Table 2. Comprehensive assessment of first-calf heifers of Russian Black Pied breed, in points

\begin{tabular}{|c|c|c|}
\hline \multirow{2}{*}{ Indicator } & \multicolumn{2}{|c|}{ Points } \\
\cline { 2 - 3 } & $\overline{\mathrm{X}} \pm S_{\bar{X}}$ & $\mathrm{Cv}, \%$ \\
\hline Torso volume & $86.8 \pm 0.5$ & 7.5 \\
\hline Dairy traits & $87.0 \pm 0.5$ & 7.7 \\
\hline Legs & $84.7 \pm 0.6$ & 9.2 \\
\hline Udder & $83.7 \pm 0.6$ & 9.6 \\
\hline General appearance & $85.4 \pm 0.4$ & 7.0 \\
\hline General score & $85.0 \pm 0.4$ & 6.6 \\
\hline
\end{tabular}

As a result of a general assessment of the body type of animals, the cows scored 85.0 points and were assigned (on average in the evaluated group) to the "Excellent" conformation complex class. Judging by the fact that the mean error of the total animal score is low $(0.4$ points), and also because the coefficient of variation of this trait is low (6.6\%), it means that the estimated first-calf cows underwent a fairly clear selection of body type and the herd was aligned on this basis. 
However, it should be noted that in the studied group of Russian Black Pied cattle there were animals of various complex classes, except for the "Bad" one (Figure 2).

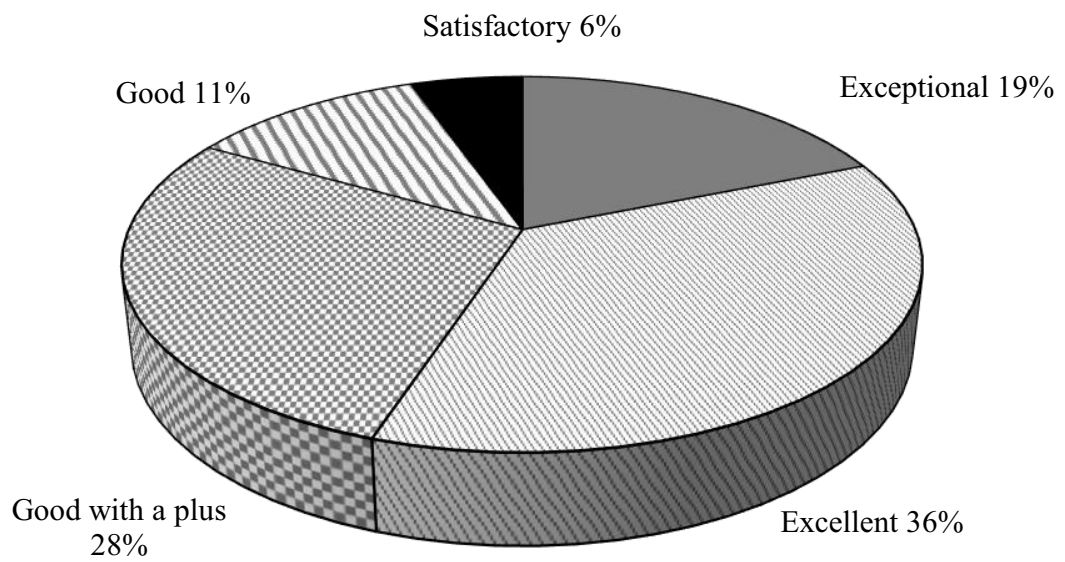

Fig. 2. Share of first-calf heifers of various conformation complex classes, in $\%$

Most heifers were within the "Excellent" complex class (36.0\%), less within "Satisfactory" (6.0\%). The second largest class was "Good with a plus" (28.0\%).

There was a relative evenness of the animals according to the conformation complex class in the studied group of first-calf heifers of Russian Black Pied breed, which makes it possible to conduct further comparative analysis.

Body types of cows characterizes their productive capabilities. During the breeding of representatives of the same breed, the resulting livestock differs in appearance and requires a special approach when breeding.

Indicators of a comprehensive assessment of the confromation (system B) give an idea of cows' body types and are somehow related to their productivity. The cow's comprehensive class serves as an indicator of its use and is usually associated with its lifelong milk production. The relationship between a comprehensive assessment and indicators of milk productivity is noted, when assessing animals in appearance.

It was found that milk yield and milk quality of cows of different complex classes differ (Table 3).

The milk yield in the first 100 days of lactation of first-calf heifers of the "Excellent" complex class is higher than in other groups by an average of $127.5 \mathrm{~kg}(5.8 \%)$. Moreover, the difference in milk yield during the milking period of the studied cows between the classes "Excellent" and "Satisfactory" amounted to $257.6 \mathrm{~kg}(11.8 \%)$ due to lack of reliability.

Table 3. Milk yield and lactation characteristics of first-calf heifers of Russian Black Pied breed, depending on the conformation complex class

\begin{tabular}{|c|c|c|}
\hline Indices, complex class & $\overline{\mathrm{X}} \pm \mathrm{S}_{\bar{X}}$ & $\mathrm{Cv}, \%$ \\
\hline \multicolumn{2}{|c|}{ "Exceptional" } \\
\hline Milk yield for 100 days in $\mathrm{kg}$ & $2177.8 \pm 80.5$ & 21.5 \\
\hline For 305 days & $5381.5 \pm 199.2$ & 21.6 \\
\hline For one lactation & $6090.1 \pm 384.9$ & 36.9 \\
\hline Lactation duration in days & $361.8 \pm 17.1$ & 27.5 \\
\hline Lactation constancy coefficient in \% & $59.4 \pm 0.6$ & 5.6 \\
\hline Milkyielding capacity in $\mathrm{kg}$ & $1034.5 \pm 34.1$ & 19.2 \\
\hline \multicolumn{2}{|c}{} \\
\hline \multicolumn{2}{|c|}{} \\
\hline
\end{tabular}




\begin{tabular}{|c|c|c|}
\hline Milk yield for 100 days in $\mathrm{kg}$ & $2137.5 \pm 55.0$ & 20.9 \\
\hline For 305 days & $5220.6 \pm 131.1$ & 20.4 \\
\hline For one lactation & $5721.4 \pm 184.1$ & 26.1 \\
\hline Lactation duration in days & $350.3 \pm 9.7$ & 22.6 \\
\hline Lactation constancy coefficient in \% & $58.8 \pm 0.6$ & 8.6 \\
\hline Milk yielding capacity in $\mathrm{kg}$ & $1024.6 \pm 26.8$ & 21.3 \\
\hline \multicolumn{3}{|c|}{ "Good with a plus" } \\
\hline Milk yield for 100 days in $\mathrm{kg}$ & $2160.2 \pm 65.2$ & 21.6 \\
\hline For 305 days & $5463.8 \pm 144.2 *$ & 18.8 \\
\hline For one lactation & $6220.2 \pm 247.7$ & 28.4 \\
\hline Lactation duration in days & $368.7 \pm 13.1$ & 25.4 \\
\hline Lactation constancy coefficient in \% & $60.4 \pm 0.5^{*}$ & 6.1 \\
\hline Milk yielding capacity in $\mathrm{kg}$ & $1064.7 \pm 30.5^{*}$ & 20.4 \\
\hline \multicolumn{3}{|c|}{ "Good" } \\
\hline Milk yield for 100 days in $\mathrm{kg}$ & $1983.5 \pm 99.8$ & 22.5 \\
\hline For 305 days & $5123.4 \pm 289.3$ & 25.3 \\
\hline For one lactation & $5482.7 \pm 376.9$ & 30.7 \\
\hline Lactation duration in days & $332.1 \pm 15.2$ & 20.4 \\
\hline Lactation constancy coefficient in \% & $60.9 \pm 0.9 *$ & 6.5 \\
\hline Milk yielding capacity in $\mathrm{kg}$ & $976.0 \pm 55.2$ & 25.3 \\
\hline \multicolumn{3}{|c|}{ "Satisfactory" } \\
\hline Milk yield for 100 days in $\mathrm{kg}$ & $1920.2 \pm 239.9$ & 37.5 \\
\hline For 305 days & $4033.3 \pm 596.6$ & 44.4 \\
\hline For one lactation & $4782.0 \pm 931.4$ & 58.4 \\
\hline Lactation duration in days & $361.1 \pm 37.3$ & 31.0 \\
\hline Lactation constancy coefficient in \% & $49.8 \pm 3.8$ & 22.7 \\
\hline Milk yielding capacity in $\mathrm{kg}$ & $772.3 \pm 117.0$ & 45.4 \\
\hline
\end{tabular}

Over a period of 305 days and the entire lactation, the maximum milk was obtained from the cows of the "Good with a plus" complex class (5463.8 and $6220.2 \mathrm{~kg}$, respectively). The difference with the other groups in this case amounted to an average of $524.1 \mathrm{~kg}(9.6 \%)$ and $701.1 \mathrm{~kg}(11.3 \%)$, respectively. It should be noted that the first-calf heifers of the "Good with a plus" complex class differed by $1430.5 \mathrm{~kg}(26.2 \%)(\mathrm{p}<0.05)$ and $1438.2 \mathrm{~kg}(23.1 \%)$ from the "Satisfactory" cows in milk yield for 305 days and for entire lactation, respectively.

The constancy coefficient, characterizing the course of lactation, is higher in cows of the "Good" and "Good with a plus" complex classes, compared with the other evaluated groups by an average of $4.7 \%$. The difference with the coefficient of constancy of lactation of "Satisfactory" class cows in this case was $10.9 \%(\mathrm{p}<0.05)$.

On average, all animals had a complete lactation lasting for 355.5 days. It should be noted that shorter lactation was observed in cows of the "Good" complex class and it was for 332.1 days, which was on average 28.4 days (7.9\%) less than in the other groups.

The milk yielding capacity characterizes the amount of milk yielded per $100 \mathrm{~kg}$ of live weight of the animal and is an important productive trait. It was found that the milk yielding capacity was higher for first-calf heifers of the "Good with a plus" complex class than for animals of other groups by an average of $112.8 \mathrm{~kg}$. We also noted that the milk yielding capacity of cows of the "Good with a plus" class is $292.4 \mathrm{~kg}$ more than that of the animals of the "Satisfactory" class $(\mathrm{p}<0.05)$. As is known, values of the milk yielding capacity below $800 \mathrm{~kg}$ are not desirable, since it cannot indicate a dairy type of animals. Cows of the complex class "Satisfactory" had the milk yielding capacity of $772.3 \mathrm{~kg}$.

First-calf heifers of the "Exceptional" class were the most dairy ones. Their mass fraction of fat in milk for the first 100 days and 305 days of lactation is higher by $0.17(\mathrm{p}<0.01)$ and $0.21 \%(\mathrm{p}<0.001)$, respectively, in comparison with other groups of animals evaluated on average (Table 4). 
Table 4. Mass fraction of fat in milk of first-calf heifers of Russian Black Pied breed depending on the conformation complex class

\begin{tabular}{|c|c|c|}
\hline Indices, complex class & $\overline{\mathrm{X}} \pm S_{\bar{X}}$ & $\mathrm{Cv}, \%$ \\
\hline \multicolumn{3}{|c|}{ "Exceptional" } \\
\hline Mass fraction of fat in milk for 100 days in $\%$ & $3.83 \pm 0.07$ & 11.27 \\
\hline For 305 days in $\%$ & $3.83 \pm 0.05$ & 8.03 \\
\hline Amount of milkfat for 100 days in $\mathrm{kg}$ & $83.40 \pm 3.53$ & 24.69 \\
\hline For 305 days in $\mathrm{kg}$ & $205.33 \pm 7.47$ & 21.20 \\
\hline \multicolumn{3}{|c|}{ "Excellent" } \\
\hline Mass fraction of fat in milk for 100 days in $\%$ & $4.03 \pm 0.07 * *$ & 13.83 \\
\hline For 305 days in $\%$ & $3.99 \pm 0.05 * * *$ & 10.63 \\
\hline Amount of milkfat for 100 days in $\mathrm{kg}$ & $86.11 \pm 2.73$ & 25.73 \\
\hline For 305 days in $\mathrm{kg}$ & $207.33 \pm 5.40 * *$ & 21.17 \\
\hline \multicolumn{3}{|c|}{ "Good with a plus" } \\
\hline Mass fraction of fat in milk for 100 days in $\%$ & $3.97 \pm 0.08$ & 14.33 \\
\hline For 305 days in $\%$ & $3.85 \pm 0.07$ & 13.85 \\
\hline Amount of milkfat for 100 days in $\mathrm{kg}$ & $85.57 \pm 3.11$ & 25.96 \\
\hline For 305 days in $\mathrm{kg}$ & $205.86 \pm 7.38$ & 25.61 \\
\hline \multicolumn{3}{|l|}{ "Good" } \\
\hline Mass fraction of fat in milk for 100 days in $\%$ & $3.98 \pm 0.12$ & 13.29 \\
\hline For 305 days in $\%$ & $3.88 \pm 0.09$ & 10.77 \\
\hline Amount of milkfat for 100 days in $\mathrm{kg}$ & $78.41 \pm 4.31$ & 24.56 \\
\hline For 305 days in $\mathrm{kg}$ & $196.21 \pm 10.14$ & 23.12 \\
\hline \multicolumn{3}{|c|}{ "Satisfactory" } \\
\hline Mass fraction of fat in milk for 100 days in $\%$ & $3.66 \pm 0.13$ & 10.47 \\
\hline For 305 days in $\%$ & $3.57 \pm 0.11$ & 9.10 \\
\hline Amount of milkfat for 100 days in $\mathrm{kg}$ & $70.23 \pm 8.48$ & 36.22 \\
\hline For 305 days in $\mathrm{kg}$ & $145.45 \pm 21.69$ & 44.73 \\
\hline
\end{tabular}

A low percentage of fat in milk with a fairly low milk yield in the group of "Satisfactory" cows showed the lowest milkfat content among different animals for different periods of lactation. So, when comparing with other evaluated groups, the difference in milkfat in this case averaged $13.1 \mathrm{~kg}(15.7 \%)$ for 100 days of lactation, and $58.2 \mathrm{~kg}(28.6 \%)$ for 305 days of lactation $(\mathrm{p}<0.01)$.

The mass fraction of protein in milk (Table 5) for the first 100 and 305 days of lactation is higher in cows of the "Good" complex class compared with the other groups by an average of $0.07 \%$ and $0.06 \%$, respectively. It should be noted that the indicator of the mass fraction of protein in milk is quite equalized among the studied groups and is in the range of 2.97$3.10 \%$. The coefficient of variation of the trait does not exceed $11.3 \%$.

The amount of milk protein in the "Good with a plus" complex class is on average $4.3 \mathrm{~kg}$ $(6.6 \%)$ more during the entire lactation period; and $17.9 \mathrm{~kg}(10.7 \%)$ more during 305 days of lactation. At the same time, the smallest values of this indicator were observed in the "Satisfactory" group: for 100 days of lactation $-58.77 \mathrm{~kg}$, for 305 days of lactation -120.96 $\mathrm{kg}$. The difference of performance compared with the "Good with a plus" class was 7.98 and $46.9 \mathrm{~kg}$ of milk protein $(\mathrm{p}<0.01)$, respectively, for lactation periods. 
Table 5. Content of milk protein of first-calf heifers of Russian Black Pied breed depending on the conformation complex class

\begin{tabular}{|c|c|c|}
\hline Indices, complex class & $\bar{X} \pm S_{\bar{X}}$ & $\mathrm{Cv}, \%$ \\
\hline \multicolumn{3}{|c|}{ "Exceptional" } \\
\hline Mass fraction of protein in milk for 100 days in $\%$ & $3.00 \pm 0.03$ & 6.07 \\
\hline For 305 days in $\%$ & $3.03 \pm 0.02$ & 3.63 \\
\hline Amount of milk protein for 100 days in $\mathrm{kg}$ & $65.49 \pm 2.63$ & 23.44 \\
\hline For 305 days in $\mathrm{kg}$ & $163.79 \pm 6.72$ & 23.93 \\
\hline \multicolumn{3}{|c|}{ "Excellent" } \\
\hline Mass fraction of protein in milk for 100 days in $\%$ & $3.00 \pm 0.03$ & 7.49 \\
\hline For 305 days in $\%$ & $3.02 \pm 0.02$ & 4.60 \\
\hline Amount of milk protein for 100 days in $\mathrm{kg}$ & $64.28 \pm 1.86$ & 23.55 \\
\hline For 305 days in $\mathrm{kg}$ & $157.87 \pm 4.32$ & 22.25 \\
\hline \multicolumn{3}{|c|}{ "Good with a plus" } \\
\hline Mass fraction of protein in milk for 100 days in $\%$ & $3.09 \pm 0.05$ & 10.54 \\
\hline For 305 days in $\%$ & $3.06 \pm 0.03$ & 5.83 \\
\hline Amount of milk protein for 100 days in $\mathrm{kg}$ & $66.75 \pm 2.21$ & 23.60 \\
\hline For 305 days in $\mathrm{kg}$ & $167.95 \pm 5.03 *$ & 21.39 \\
\hline \multicolumn{3}{|c|}{ "Good" } \\
\hline Mass fraction of protein in milk for 100 days in $\%$ & $3.10 \pm 0.08$ & 11.32 \\
\hline For 305 days in $\%$ & $3.08 \pm 0.04$ & 5.92 \\
\hline Amount of milk protein for 100 days in $\mathrm{kg}$ & $61.27 \pm 3.15$ & 23.02 \\
\hline For 305 days in $\mathrm{kg}$ & $157.72 \pm 9.33$ & 26.46 \\
\hline \multicolumn{3}{|c|}{ "Satisfactory" } \\
\hline Mass fraction of protein in milk for 100 days in $\%$ & $3.04 \pm 0.05$ & 4.87 \\
\hline For 305 days in $\%$ & $2.97 \pm 0.04$ & 3.67 \\
\hline Amount of milk protein for 100 days in $\mathrm{kg}$ & $58.77 \pm 7.61$ & 38.86 \\
\hline For 305 days in $\mathrm{kg}$ & $120.96 \pm 18.09$ & 44.87 \\
\hline
\end{tabular}

Cows that are being used for a long time, as a rule, distinguish throughout their life by their good productivity, solid conformation and health, and resistance to diseases.

The indicators of productive longevity of cows of various conformation complex classes were analyzed. It was established (Table 6) that only the "Excellent" cows were culled due to the low yield $(6.2 \%)$. Genital and udder diseases caused culling of cows of the classes "Excellent" (6.2\% both) and "Good with a plus" (9.1\% both).

Table 6. Culling of cows of various body types, in \%

\begin{tabular}{|c|c|c|c|c|c|}
\hline \multirow{2}{*}{ Reasons for culling } & \multicolumn{5}{|c|}{ Complex class } \\
\cline { 2 - 6 } & "Exceptional” & "Excellent" & $\begin{array}{c}\text { "Good with } \\
\text { a plus" }\end{array}$ & "Good” & "Satisfactory \\
”
\end{tabular}




\begin{tabular}{|c|c|c|c|c|c|}
\hline $\begin{array}{c}\text { Digestive system } \\
\text { diseases }\end{array}$ & 0.0 & 12.5 & 0.0 & 0.0 & 0.0 \\
\hline $\begin{array}{c}\text { Respiratory system } \\
\text { diseases }\end{array}$ & 9.1 & 0.0 & 0.0 & 0.0 & 0.0 \\
\hline $\begin{array}{c}\text { Other non- } \\
\text { communicable } \\
\text { diseases }\end{array}$ & 18.2 & 18.8 & 18.2 & 25.0 & 0.0 \\
\hline $\begin{array}{c}\text { Difficult births and } \\
\text { complications }\end{array}$ & 9.1 & 0.0 & 0.0 & 0.0 & 33.3 \\
\hline Barrenness & 9.1 & 0.0 & 0.0 & 50.0 & 0.0 \\
\hline $\begin{array}{c}\text { Conformation } \\
\text { disadvantages }\end{array}$ & 0.0 & 6.3 & 0.0 & 0.0 & 0.0 \\
\hline Accidents, injuries & 0.0 & 0.0 & 9.1 & 25.0 & 0.0 \\
\hline Sold cows & 0.0 & 0.0 & 9.1 & 0.0 & 0.0 \\
\hline Other reasons & 18.2 & 6.2 & 18.2 & 0.0 & 0.0 \\
\hline Reason unknown & 0.0 & 0.0 & 0.0 & 0.0 & 33.3 \\
\hline
\end{tabular}

As a result of limb diseases, animals of the "Good with a plus" class were culled on average by $17.5 \%$ more often compared to the "Exceptional" and "Excellent" cows. At the same time, cows of the "Exceptional" class were culled due to respiratory diseases $(9.1 \%)$, other non-communicable diseases (18.2\%) and other causes $(18.2 \%)$.

Animals of the "Excellent" complex class were culled due to digestive diseases $(12.5 \%)$ more often than the other groups. At the same time, cows of the "Exceptional" class were culled due to respiratory diseases $(9.1 \%)$, other non-communicable diseases $(18.2 \%)$ and other causes $(18.2 \%)$.

The studied cows of the "Good" class were culled due to such reasons as barrenness $(50.0 \%)$, accidents and injuries $(25.0 \%)$. Animals of the "Satisfactory" class were culled due to difficult birth (33.3\%) and metabolic diseases (33.4\%).

Cows of the "Excellent" class were culled due to conformation disadvantages $-6.3 \%$, which indicates that the physique of animals undergoes some changes during their life and use, therefore a comprehensive assessment of the conformation must be carried out throughout the entire period of animal use.

The life span and the period of production use of animals are undoubtedly interrelated. Indicators of life expectancy and duration of production use are higher in cows of the "Good" class than in animals of the other groups, on average, by 2.6 years and 2.1 lactation, respectively (Table 7).

The indicators in this case are higher than in the other groups on average by 2.6 years and 2.1 lactations $(\mathrm{p}<0.05)$. In addition, cows of the complex classes "Exceptional" and "Excellent" possessed quite long life expectancy and animal use.

Table 7. Life expectancy and duration of production use of cows of various body types

\begin{tabular}{|c|c|c|c|c|}
\hline \multirow{2}{*}{ Complex class } & \multicolumn{4}{|c|}{ Indices } \\
\cline { 2 - 5 } & \multicolumn{2}{|c|}{$\begin{array}{c}\text { Life expectancy of cows in } \\
\text { years }\end{array}$} & $\begin{array}{c}\text { Duration of production use } \\
\text { of cows in lactations }\end{array}$ \\
\cline { 2 - 5 } & $\overline{\mathrm{X}} \pm S_{\bar{X}}$ & $\mathrm{Cv}, \%$ & $\overline{\mathrm{X}} \pm S_{\bar{X}}$ & $\mathrm{Cv}, \%$ \\
\hline "Exceptional" & $7.0 \pm 1.38$ & 52.2 & $4.9 \pm 1.20$ & 65.6 \\
\hline "Excellent" & $7.8 \pm 1.16$ & 55.4 & $5.8 \pm 0.89$ & 57.4 \\
\hline "Good with a plus" & $6.5 \pm 1.09$ & 55.6 & $4.3 \pm 0.78$ & 59.5 \\
\hline "Good" & $9.6 \pm 1.20^{*}$ & 28.1 & $6.8 \pm 1.56^{*}$ & 51.4 \\
\hline "Satisfactory" & $6.7 \pm 0.67$ & 17.3 & $3.7 \pm 0.33$ & 15.7 \\
\hline
\end{tabular}


The life expectancy of cows of the indicated groups is longer in comparison with animals of the "Satisfactory" class by an average of 1.2 years, and the period of production use - by an average of 0.9 lactations. At the same time, cows of the "Good with a plus" class lagged behind the animals of the "Exceptional" and "Excellent" classes according to these indicators by an average of 0.9 years and 1.1 lactations, respectively.

Most of the offspring were obtained from the "Excellent" cows - 1028 calves (Table 8).

Twin calves were born mainly in the group of cows of the "Exceptional" class $-6.3 \%$, but also there were more stillborn calves than in the other groups (on average $11.9 \%$ higher). In addition, abortions and malformations of calves were observed only in this group $-5.2 \%$.

Table 8. The results of calving of cows of various body types

\begin{tabular}{|c|c|c|c|c|c|}
\hline \multirow[b]{2}{*}{ Results of calving } & \multicolumn{5}{|c|}{ Complex class } \\
\hline & "Exceptional" & "Excellent" & $\begin{array}{l}\text { "Good } \\
\text { with a } \\
\text { plus"” }\end{array}$ & "Good" & "Satisfactory" \\
\hline $\begin{array}{c}\text { Cows evaluated in } \\
\text { total }\end{array}$ & 35 & 67 & 52 & 21 & 10 \\
\hline Offspring in total & 475 & 1028 & 572 & 202 & 70 \\
\hline including bulls & 144 & 488 & 217 & 97 & 3 \\
\hline$\%$ & 30.5 & 47.4 & 38 & 47.9 & 4.8 \\
\hline heifers & 239 & 531 & 350 & 105 & 60 \\
\hline$\%$ & 50.4 & 51.6 & 61.2 & 52.1 & 85.7 \\
\hline twin calves & 30 & 48 & 19 & 0 & 0 \\
\hline$\%$ & 6.2 & 4.7 & 3.3 & 0 & 0 \\
\hline twin heifers & 2 & 2 & 0 & 0 & 0 \\
\hline$\%$ & 33.3 & 20 & 0 & 0 & 0 \\
\hline twin bulls & 4 & 8 & 4 & 0 & 0 \\
\hline$\%$ & 66.5 & 80 & 100 & 0 & 0 \\
\hline Stillborn calves & 69 & 9 & 5 & 0 & 7 \\
\hline$\%$ & 14.7 & 0.9 & 0.8 & 0 & 9.5 \\
\hline $\begin{array}{c}\text { Abortions, } \\
\text { malformations }\end{array}$ & 23 & 0 & 0 & 0 & 0 \\
\hline$\%$ & 5.2 & 0 & 0 & 0 & 0 \\
\hline
\end{tabular}

Lifetime productivity indicators are higher in the "Good" complex class, in which lifetime milk yield is higher on average by $10525.4 \mathrm{~kg}(27.6 \%)(\mathrm{p}<0.05)$, milkfat - on average 263.2 $\mathrm{kg}(20.1 \%)(\mathrm{p}<0.05)$, than in other groups (Table 9).

Table 9. Lifetime productivity of cows of various body types

\begin{tabular}{|c|c|c|c|c|c|c|}
\hline \multirow{3}{*}{ Complex class } & \multicolumn{6}{|c|}{ Productivity of cows } \\
\hline & \multicolumn{2}{|c|}{ lifetime } & \multicolumn{2}{|c|}{ for one year of use } & \multicolumn{2}{|c|}{ for one day of life } \\
\hline & $\begin{array}{l}\text { milk yield } \\
\text { in } \mathrm{kg}\end{array}$ & $\begin{array}{c}\text { milkfat } \\
\text { in kg }\end{array}$ & $\begin{array}{c}\text { milk } \\
\text { yield in } \\
\mathrm{kg}\end{array}$ & $\begin{array}{c}\text { milkfat in } \\
\mathrm{kg}\end{array}$ & $\begin{array}{l}\text { milk } \\
\text { yield } \\
\text { in } \mathrm{kg}\end{array}$ & $\begin{array}{c}\text { milkfat in } \\
\mathrm{kg}\end{array}$ \\
\hline "Exceptional" & $\begin{array}{l}27564.1 \\
\pm 6200.5\end{array}$ & $\begin{array}{c}888.7 \\
\pm 165.4\end{array}$ & $\begin{array}{l}6146.8 \\
\pm 743.9\end{array}$ & $\begin{array}{l}217.0 \\
\pm 36.7\end{array}$ & $\begin{array}{l}10.3 \\
\pm 0.9\end{array}$ & $\begin{array}{c}0.36 \\
\pm 0.05\end{array}$ \\
\hline "Excellent" & $\begin{array}{l}28450.3 \\
\pm 2313.5\end{array}$ & $\begin{array}{c}1099.9 \\
\pm 87.1\end{array}$ & $\begin{array}{l}5913.7 \\
\pm 346.7\end{array}$ & $\begin{array}{l}228.9 \\
\pm 12.9\end{array}$ & $\begin{array}{l}10.8 \\
\pm 0.4\end{array}$ & $\begin{array}{c}0.42 \\
\pm 0.02\end{array}$ \\
\hline "Good with a plus" & $\begin{array}{l}29637.0 \\
\pm 3553.4 \\
\end{array}$ & $\begin{array}{l}1194.6 \\
\pm 146.2\end{array}$ & $\begin{array}{c}7581.6 \\
\pm 309.1^{* *} \\
\end{array}$ & $\begin{array}{c}333.4 \\
\pm 15.7^{*} \\
\end{array}$ & $\begin{array}{l}12.5 \\
\pm 1.2 \\
\end{array}$ & $\begin{array}{c}0.49 \\
\pm 0.04 \\
\end{array}$ \\
\hline
\end{tabular}




\begin{tabular}{|c|c|c|c|c|c|c|}
\hline "Good" & $\begin{array}{c}38126.8 \\
\pm 5105.4^{*}\end{array}$ & $\begin{array}{c}1307.9 \\
\pm 135.6^{*}\end{array}$ & $\begin{array}{c}6174.4 \\
\pm 622.8\end{array}$ & $\begin{array}{c}233.6 \\
\pm 46.8\end{array}$ & $\begin{array}{c}10.8 \\
\pm 0.5\end{array}$ & $\begin{array}{c}0.39 \\
\pm 0.05\end{array}$ \\
\hline \multirow{2}{*}{ "Satisfactory” } & 24754.1 & 995.6 & 7359.3 & 323.5 & 10.1 & 0.41 \\
& \pm 3903.7 & \pm 109.9 & \pm 703.2 & \pm 38.4 & \pm 1.1 & \pm 0.07 \\
\hline
\end{tabular}

The lowest lifetime milk yield is in the "Satisfactory" group of cows and it is $2475.1 \mathrm{~kg}$. This value is lower than in the other evaluated groups by an average of $6190.5 \mathrm{~kg}$. The lowest indicator of the amount of milkfat over the whole life period belongs to animals of the "Exceptional" class - which is $888.7 \mathrm{~kg}$, which is on average $107.9 \mathrm{~kg}$ lower than in the other groups.

When recalculating the indicators for one year of use and one day of life, the cows of the "Good with a plus" class predominate. Productivity of these animals is higher on average by $1183.1 \mathrm{~kg}(15.6 \%)(\mathrm{p}<0.01)$ and $2.0 \mathrm{~kg}(16.0 \%)$ in milk yield; by $82.7 \mathrm{~kg}(24.8 \%)(\mathrm{p}<0.05)$ and $0.1 \mathrm{~kg}(18.4 \%)$ in milkfat, respectively.

\section{Conclusion}

The conformation complex class of animals affects their milk yield. Consequently, evaluating first-calf heifers by the conformation complex class is a necessary measure in each individual herd in order to increase milk production, milk quality and terms of productive longevity.

When selecting first-calf heifers, taking into account the body type, it seems possible to obtain animals of a conformation complex class not lower than "Good"; to obtain at least $5000-5500 \mathrm{~kg}$ of good quality milk with a mass fraction of fat of $3.85-3.88 \%$ and protein fraction of 3.06-3.08\% from cows of 305 days of lactation, depending on the potential of the breeding herd; to increase the duration of production use up to 4.3-6.8 lactations; to increase the level of lifelong yield to $29637.0-38126.8 \mathrm{~kg}$ of milk; to reduce the percentage of metabolic diseases and diseases of digestive and respiratory systems; to exclude or minimize the stillbirth rate

\section{References}

1. M.A. Chasovshchikova, O.M. Sheveleva, M.A. Svjazhenina, E.A. Ponomareva, A.G. Koshchaev, Journal of Pharmaceutical Sciences and Research, 9(7) 1038-1044 (2017)

2. E.I. Anisimova, N.A. Balakirev, A.G. Koshchaev, A.S. Krivonogova, Y.A. Yuldashbaev, International Journal of Engineering and Advanced Technology, 9(1), 4983-4986 (2019)

3. E.I. Anisimova, A.G. Koshchaev, O.N. Eremenko, T.V. Kalashnikova, S.V. Shabunin, International Journal of Innovative Technology and Exploring Engineering, 8(8), 3207 3211 (2019)

4. D. Abylkasymov, N.P. Sudarev, N.V. Ivanov, Animal husbandry of the South of Russia. 5(15), 21-25 (2016)

5. G.P. Babaylova, A.V. Kovrov, Agrarian Russia, 6, 34-37 (2018)

6. S.D. Batanov, I.A. Baranova, O.S. Starostina, Trends in the development of science and education, 43-6, 13-19 (2018)

7. L.P. Ikoeva, Bulletin of the Gorsky State Agrarian University, 53(2), 78-83 (2016)

8. P.S. Katmakov, V.P. Gavrilenko, A.V. Bushov, Bulletin of the Ulyanovsk State Agricultural Academy, 2(38), 122-127 (2017)

9. S.Yu. Plavinsky, G.P. Zhukova, Far Eastern Agrarian Bulletin, 3(43), 138-142 (2017) 
10. M.V. Abramova, M.S. Barysheva, Bulletin of the Buryat State Agricultural Academy, 4(53), 167-174 (2018)

11. N.I. Abramova, O.N. Burgomistrova, O.L. Khromova, G.S. Vlasova, L.N. Bogoradova AgroZooTehnika, 1(3), 2 (2018)

12. S.D. Batanov, I.A. Baranova, O.S. Starostina, Bulletin of the Bashkir State Agrarian University, 1(49), 55-62 (2019)

13. T.V. Gromova, A.P. Kosarev, P.V. Konorev, Bulletin of the Altai State Agrarian University, 6(152), 115-121 (2017)

14. M.B. Ulimbashev, Bulletin of the Bashkir State Agrarian University, 3(51), 69-74 (2019)

15. S.V. Fedotov, N.S. Belozertseva, I.M. Yakhaev, A.E. Ganse, Bulletin of the Altai State Agrarian University, 2(160), 102-106 (2018)

16. V.V. Vechorka, Y.A. Samokhina, I.A. Eremeychuk, Bulletin of Sumy National Agrarian University, 5, 30-35 (2016) 